Species 1. Sarcopsylla penetrans, Linn. Bicho de Pé.

Plate XX. Fig. 3.

Fig. $3 a$, female natural size; $3 b$, ditto magnified, distended with eggs; $3 c$, head and prothorax; $3 d$, maxillary palpus; $3 e e$, mandibles; $3 f$, lingua; $3 g$, labium ? $3 h$, one of the feet; $3 i$, part of the coil of eggs; $3 k$, ditto nearer to the anal orifice; $3 l$, one of the eggs opened.

Species 2. Sarcopsylla canis, Westw. Bicho de Cachorro.

Differentiæ specificæ haud determinatæ.

Obs.-Since this memoir was read, M. Dugès has published a memoir on the Jigger, in the Annales des Sciences Naturelles for September, 1836, in which he has traced the organization of gravid females, but has not considered it proper to separate it generically from the genus Pulex. M. Guérin, also, in his Iconographie du Règne Animal, (Insectes, pl. 2), has given figures of the insect in various states. His figures 9 and $9 a$ represent a specimen with the abdomen of the ordinary small size, and terminated by a long furcate instrument, composed of five pieces (fig. $9 f$ and $9 \mathrm{~g}$ ), and which in his descriptive text (for proof sheets of the first part of which I am indebted to him) he regards as a male, with exserted organs of generation, considering that the forked appendage cannot be an ovipositor, and consequently that the individual must be a male. His figure $9 b$ represents a female, with the abdomen distended as in my figure; and in his text he proposes the generic name of Dermatoplitus for the insect.

XLI. Description of a minute Crustaceous Animal from the Island of Mauritius. By Roвert Templeton, Esq. R.A.

[Read 4th Aprit, 1836.]

Class CRUSTACEA, Brisson. Lam.

Sub-class Malacostraca, Latreille.

Order AMPHIPODA ? Latreille.

Genus novum, ZEuxo.

Antennæe 4, breves, subæquales, spinis armatæ ; superiores, 3-articulatæ, articulo 1 mo multo majore; inferiores indivisæ, 5 -articulata, articulo ultimo valdè minuto.

Oculi duo : antennis superioribus contigui, in squamis subtriangularis capite articulatis inmersi. 
Corpus elongatum, semicylindricum, segmentis 13 divisum; primum maximum, 11 et 12 valdè angusta. Cauda, aut corporis ultimum segmentum, mediocriter lata, setis duobus articulatis spinosis instructa.

Pedes 14: par primum, crassum, cheliferum, multo majus; paria sequentia elongata, subsimilia, unguiculata, ungue 2di paululùm attenuati paris, longiore.

Pedes natantes ut in Squillis, è segmentis 8, 9, 10 orientes.

\section{Species unica. Zcuxo Westwoodiana.}

Body greyish, a rhomboidal black macula between and behind the eyes; another very large, mottled interiorly, with the anterior side greatest, occupying nearly the posterior mesial half of the cephalic ring. The second ring with an elongate triangular dash on each side, the apices almost meeting in the centre. The succeeding rings with the sides mottled, and a rectangular black spot on the middle part of each posteriorly.

Length $0 \cdot 14$ inch.

Among marine plants near Black River, Mauritius.

The cephalic ring of this minute crustaceous animal is somewhat conic in its form, being considerably dilated posteriorly; it has a minute rostrum projecting between the superior antennæ, and a hollow on each side exterior to those antennæ, in which rests a small articulated plate, carrying the jet black apparently compound eye. The exterior surface of this minute plate is arched, and the eye seems immersed in it, or at least the membranous covering of the plate covers also the eye. The antennæ are four, rather more than half as long as the cephalic ring, subequal, the superior composed of three joints ; the first of which is large and robust, spiny or hairy, dilated near its base, and arising from an excavation on each side of the rostrum, a little superior to the eye. The second joint is very small, a little longer than broad, and encircled at its extremity with a fringe of hairs; the third is minute, conical, the truncate extremity surmounted by four or five linear blunt styles, above which project a few long spines or hairs. The inferior antennoc are nearly as long as the superior, and arise immediately beneath the superior : they are five-jointed; the first joint short and rather thick; the second very short; third more slender and as long as the first, with a few long hairs descending from its apex; fourth joint much smaller than the last, but similar in form, and also armed with one or two long hairs; fifth joint excessively minute; its apex margined with blunt spines, from whose centre proceed three or four very long and acuminated spines or hairs. 
From the cephalic ring belind, and from a slight eminence, arises the anterior leg, or arm, exceedingly robust, reaching to beyond the middle of the antennæ, cheliferous; its second joint projects like an elbow behind the apex of the first, which descends obliquely outwards, and is rounded, thick and short. The third joint is much smaller, irregularly triangular, and has the fourth articulated to it superiorly, the articulating surface looking also slightly forwards and inwards. The fourth joint is much the largest, thick and sloort, and carries the cheliferous joint. This latter is nearly of the same dimensions as that first described; it curves downwards about its middle nearly at right angles; the posterior part of the chela fixed, curved inwards, broad, with a blunt tooth at its extremity directed inwards, and rows of hairs along its edges; the anterior part is moveable, much narrower, and arched, so that its apex rests against the blunt tooth of the fixed part.

When one of these cheliferous legs is removed, there is exposed, included between them, the manducatory apparatus, consisting of a pair of mandibles?, contiguous posteriorly, separated anteriorly ; composed of four or five joints, becoming more and more flattened as they approach the apex, of irregular form; the last small, flat, curved inwards, its apex thickly fringed with elongate curved hairs, and arising from the extremity of a curved joint, to whose inferior surface is affixed a semicircular plate, the free elge of which is also closely fringed with hairs; these parts are kept by the animal in perpetual motion, most probably entangling the minute animals which served it for food.

Immediately above these appear a pair of maxillæ? somewhat rhomboidal.when looked at from above; the contiguous edges straight; the anterior irregular, with a few spines; exterior rounded, appearing as if articulated to one of the basal joints of the mandibles: the minute size and transparency, however, makes it impossible to ascertain exactly to which of them. They are also moved, but not with any thing like the velocity of the above described parts.

Above these, and with the fringed extremities reaching nearly to the end of the mandibles, are on each side two other elongate, biarticulate bodies (palpi?), robust and rounded, whose extremities are fringed with short hairs; the hairs of the lower much less coarse and longer than those on the upper. When the tip of the upper is separated, it appears broad and hollowed, as if to receive the extremity of that adjoining inferior. Both lie in immediate proximity with a superior lip, whose extremity carries a minute palpiform process, directed somewhat backwards. 
The next ring or neck is very short, and bears the second leg. This leg is slender, longer than any of the succeeding; the joints after the second being in succession, each longer than that preceding; spiny; the apex carrying a very long, gently curved claw.

The five succeeding rings are tolerably large, of nearly equal breadth, the central rather the longest, and each supporting a pair of legs, which are five-jointed; the second joint very long and thick, the rest about one half as long and spiny; the fourth and fifth toothed on the posterior edge, and the fifth carrying a short, strong, hooked claw. The rest of the rings are successively smaller, except the caudal, which extends a length equal to that of two which precede it ; the first three are furnished with swimming feet, which are double jointed, the apical carrying two semicircular lamellæ, articulated by one extremity, the curved edges of which are furnished with very long hairs, and the straight edge of one with two blunt wavy spines. The caudal ring has a fissure on each side dividing its edge into three parts, the central terminated by a pencil of hairs, the lateral of each side with a sevenjointed style, whose first joint it conceals; the joints of these styles are elongate, and apically furnished with two or three spines or long hairs, those from the terminal very long.

This singular little animal, which I have inscribed to my friend Mr. Westwood, would seem to take precedence of all the genera in the division Amphipoda of Latreille, to which I believe it correctly belongs. It resembles, however, very much in its gait and habits the Squilla, and the resemblance is still more striking, from the excessive developement of the hand, and the mode in which it is carried, pressed close up against the cephalic ring; and also in the form of the swimming feet. Nevertheless the chelæ, the simply clawed feet, the styled tail, subpedunculate eye, and the mode of origin of the antennæ, reduce it to its proper place among the Gammarida, but in a section distinct from any as yet described, [and nearly allied to Tanais and Rhcea of M. Edwards. -J. O. W.]

\section{DESCRIPTION OF THE FIGURES.}

\section{Plate XVIII.}

Fig. 1. Zeuxo Westwoodiana considerably magnified.

2. Anterior part of the cepbalic ring, exhibiting the eyes and mode of origin of the superior antenna.

3. The same seen laterally.

4. The cephalic ring, with one of the hands removed to show the positions occupied by the parts of the mouth when in situ; $f$, the upper lip carrying the minute process. 
Fig. 5. Tip of the superior antenna.

6. Tip of the inferior.

7. The exterior of the first pair of legs or arms.

8. The inner surface of the first legs.

9. The manducatory apparatus detached; $a$, the mandibles ?; $b$, the max illæ ?; $c, d$, palpi ?; $d^{*}$, apex of the superior seen from below ; $e$, part of the upper lip in situ carrying the minute palpiform process.

10. The mandibles ? and maxilla? from above; $n$, the penultimate joint.

11. The same from beneath; $m$, the lamella attached to the inferior surface of the penultimate joint $n$, fig. 10 .

12. The same seen from inside.

13. The second pair of legs.

14. The third pair of legs.

15. Last joint of the swimming feet.

16. The apex of the caudal ring with the style.

17. The joint of the style which is concealed with the lateral part of the caudal ring.

Obs.-The organs on one side of the animal alone are delineated, in order to prevent confusion.

\section{Notes respecting the Nest of Cteniza nidulans. By W. SELLs, Esq.}

[Read 2d January, 1837.]

$H_{A v I N G}$ received from the island of Jamaica at different times, in the course of the last twelve years, a number of the nests of Cteniza nidulans, with many specimens of the ingenious artisans which construct and inhabit them, I have been afforded favourable opportunities for making observations upon this curious and interesting structure, and which we may rank among the chefd'œuvres of insect architecture. Those remarks are now brought together, and, with some sketches of the nest and insect, are submitted to the notice of the Society.

Large districts of the central parts of Jamaica, in which island I resided above twenty years, consist of a reddish argillaceous earth upon a limestone honey-comb rock, and the country is so hilly as to be termed mountainous; the red dirt, as it is commonly called, occupies the vallies, and more scantily covers the hills, where it is mixed with vegetable mould and nodules of the rock; the latter is in vast masses, and sometimes appears in large isolated portions, with perpendicular surfaces of from ten to thirty feet square; its cellular formation denotes its igneous origin, and 